\title{
11. GEODYNAMIC EVOLUTION OF THE CÔTE D'IVOIRE-GHANA TRANSFORM MARGIN: AN OVERVIEW OF LEG 159 RESULTS ${ }^{1}$
}

\author{
Christophe Basile, ${ }^{2}$ Jean Mascle, ${ }^{3}$ Jean Benkhelil, ${ }^{4}$ and Jean-Pierre Bouillin ${ }^{2}$
}

\begin{abstract}
A synthesis of shipboard and postcruise studies performed on Ocean Drilling Program (ODP) Leg 159 data leads to several important modifications on previously proposed models for the Côte d'Ivoire-Ghana Transform Continental Margin evolution. Siliciclastic sedimentation occurred from Aptian through late Albian times in a wrench tectonic (possibly pull-apart basin) setting and was submitted to high geothermal gradients. This tectonically active transform zone jumped twice from the southern edge of the Ivorian Basin (the adjacent divergent margin) to the southernmost oceanic border of the Gulf of Guinea. Each jump correlates with a localized uplift, coeval with the end of tectonic deformation and heating. As a consequence, the erosional unconformities capping the Early Cretaceous deformed sequences are not thought to be coeval at all ODP sites. A progressive southward migration of the active transform may have been initiated in early Albian times, when continental breakup occurred within the adjacent rifted Ivorian Basin. The early northward tilting of the marginal ridge appears to be prior to the late Albian, and has led to the development of a fringing reef along its northern slope. A second migration of the transform fault zone occurred in the late Albian-early Cenomanian at the end of the active shear between the African and Brazilian continental crusts. During Late Cretaceous times, the transform margin experienced continuous subsidence leading to the progressive upslope migration of the reef. An increasing subsidence rate characterized the early Coniacian, close to the time when the first continent/ocean transform transition occurred. No specific thermal event or uplift can be associated with this continent/ocean active transform boundary, which is characterized only by an increase of the marginal ridge's northward tilting. ODP Leg 159 results clearly exclude thermal conduction from the oceanic lithosphere to the continental one as the main process resulting in transform margin tilting and uplift. Clues to these processes have to be searched in the functioning of the active transform fault during both intracontinental and continental/oceanic stages.
\end{abstract}

\section{INTRODUCTION}

One of the main goals in drilling the Côte d'Ivoire-Ghana (CIG) transform continental margin was to better understand the evolution, in time and space, of a continent to ocean transition across a transform fault. The Côte d'Ivoire-Ghana margin is probably the best known transform margin, mainly from marine geophysical cruises and scientific dives conducted prior to drilling (see review and references of previous studies in Basile et al., 1996), and from data collected during Ocean Drilling Program (ODP) Leg 159, which increased considerably our knowledge of the tectonic and sedimentary evolution of this transform margin.

Located on the northern edge of the Gulf of Guinea (Fig. 1A), the Côte d'Ivoire-Ghana margin, like most transform margins, is characterized chiefly by two main morphostructural features (Fig. 1B):

1. A very steep (up to $20^{\circ}$ ) and narrow (less than $40 \mathrm{~km}$ ) transition zone between the continental and oceanic crusts. This sharp transition is clearly seen in the bathymetry and in Moho topography (Sage et al., 1997b; Edwards et al., 1997). This zone is lined up with an oceanic fracture zone, in this case the Romanche fracture zone.

2. An elevated and elongated marginal ridge, now partly buried on its northern half under sediments. This ridge extends the transform domain along the border of the adjacent passive rifted (divergent) basin, the Ivorian Basin.

${ }^{1}$ Mascle, J., Lohmann, G.P., and Moullade, M. (Eds.), 1998. Proc. ODP, Sci. Results, 159: College Station, TX (Ocean Drilling Program).

${ }^{2}$ Laboratoire de Géodynamique des Chaînes de Montagne, UPRES-A CNRS 5025, 15 rue Gignoux, 38031 Grenoble Cedex, France. cbasile@ujf-grenoble.fr

${ }^{3}$ Laboratoire de Géodynamique Sous Marine, UMR-CNRS 6526 Geosciences Azur, BP48, 06230 Villefranche/Mer, France.

${ }^{4}$ URA-CNRS 715, Sedimentologie et Géochimie marines, Université de Perpignan, 66860 Perpignan, France.
Two of the four sites drilled during ODP Leg 159 (Fig. 1B) define a short cross section of this marginal ridge: Site 959 was located on the northern slope of the marginal ridge, $5 \mathrm{~km}$ north of Site 960 , which was drilled almost on top of the ridge. Site 960 and the two other sites (Sites 961 and 962) define an along-strike section of the continental transform margin edge. Site 961 is located on the western termination of the marginal ridge; Site 962 was drilled in the abyssal plain on a minor acoustic basement ridge that lies in transition toward a series of reliefs delineating the Romanche fracture zone.

According to Mascle and Blarez (1987) and Basile et al. (1993), the tectonic and sedimentary evolution of a transform translational margin can tentatively be divided into three stages during rifting and subsequent ocean opening:

1. An intracontinental transform faulting stage. This results in a tectonically active contact between two thick continental lithospheres along most of the transform fault. However, along the border of the divergent Ivorian Basin, the marginal ridge was located at a transform contact between a thick continental lithosphere and a thin one.

2. A continent/ocean active transform margin stage. During this stage the difference in thickness between the continental and the adjacent oceanic crusts is believed to have produced steep slopes similar to those we observe now in both bathymetry and Moho topography. Contrasts in thermal regimes may also have induced thermal exchanges between the two lithospheres and subsequent vertical readjustment.

3. A continent/ocean passive transform margin stage. After the accretion of the oceanic crust south of the African continent, the transform margin becomes inactive, and begins to subside thermally.

The principal results from Leg 159, as well as the synthesis proposed in this paper, have been divided into three temporal stages whose ages are mainly derived from plate tectonic motion and recon- 
A

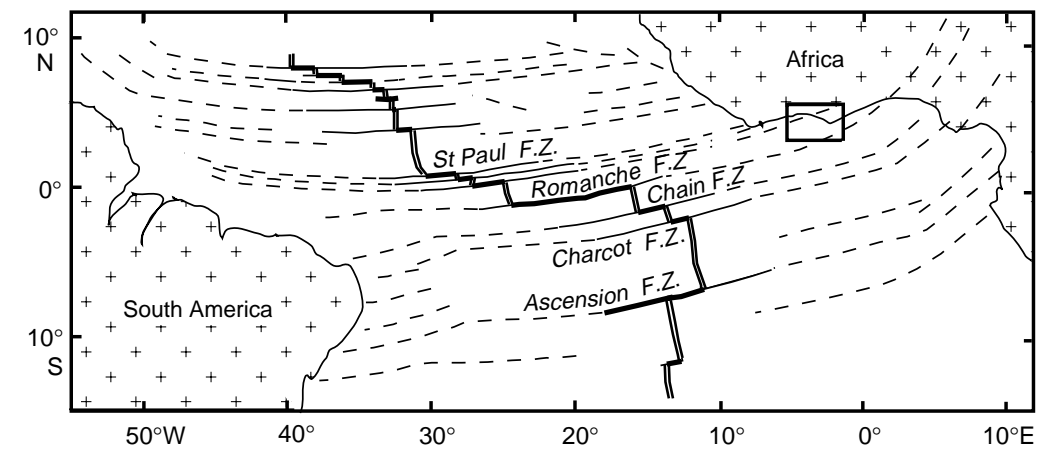

B

Figure 1. Geodynamic (A) and bathymetric (B) framework of the Côte d'Ivoire-Ghana transform margin. Boxed area in (A) is shown in detail in (B). The solid circles indicate the location of Leg 159 sites. The rectangles show the location of the multichannel seismic reflection lines shown in Figures 2 and 3.

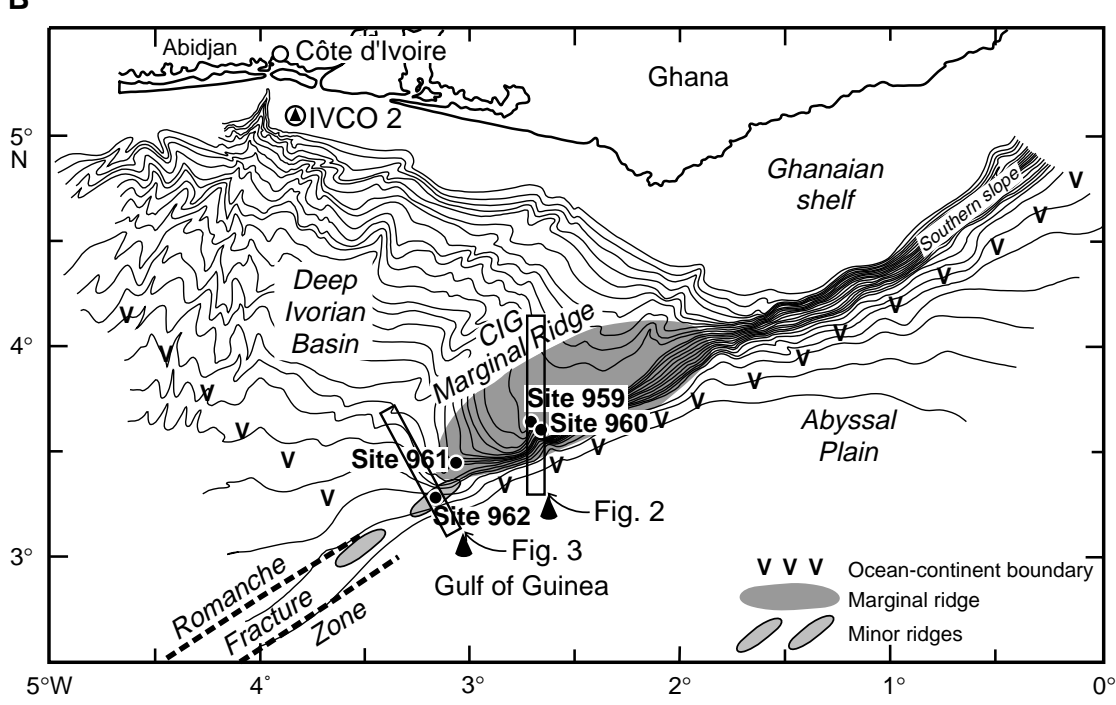

struction (e.g., Cande et al., 1988; Scotese et al., 1988). Unfortunately, the mid-Cretaceous quiet magnetic zone and the location nearby the Equator prevents any precise plate reconstruction at the time of rifting and continental breakup in the equatorial Atlantic area. The geometry and timing of oceanic opening in this area are consequently constrained chiefly by fracture-zone geometry and by the opening of the south and central Atlantic Oceans (Sibuet and Mascle, 1978) However, geodynamic models and field data (e.g., Janssen et al., 1995 ) indicate that the continental rifting (the beginning of intracontinental Stage 1) initiated during Early Cretaceous times (Aptian or older) may have occurred after the St. Helena mantle plume weakened the continental lithosphere (Wilson, 1992; Coulon et al., 1996; Hisada et al., Chap. 14, this volume). Plate breakup in the equatorial divergent basins and the first occurrence of oceanic crust west of the Ivorian Basin are thought to be Albian-Cenomanian in age. Mascle et al. (1988) believed that the last contact between the African and Brazilian continental crust and the early continent/ocean transition across the transform margin (beginning of Stage 2) occurred around Turonian times, and that the passive transform-margin Stage 3 began as the oceanic spreading center passed south of the CIG transform margin, likely in Santonian time. It is, however, important to keep in mind that the transition between Stages 1 and 2 and between Stages 2 and 3 should have been diachronous, both being older westward as the oceanic crust and ridge moved progressively from east to west with respect to the African continental crust.

Most of the models that have been proposed to explain the formation of transform margins emphasize considerable vertical motion re- corded either by erosional surfaces on shelf areas, or by the presence of uplifted and tilted prominent marginal ridges at the edges of transform margins. Uplift has been tentatively explained according to three main mechanisms: (1) tectonics, which implies either a compressional component (e.g., Blarez and Mascle, 1988) or sharp differences in tectonic subsidence (Basile et al., 1992); (2) thermally induced uplift via heating of the continental lithosphere by the adjacent oceanic lithosphere (Mascle and Blarez, 1987; Todd and Keen, 1989; Lorenzo and Vera, 1992); and (3) magmatic effects such as underplating, which are unlikely along the CIG area because of the lack of any evidence of magmatic rocks or associated magnetic anomaly coeval with the rifting. Finally, more recently, mechanical modeling has been proposed (Lorenzo and Wessel, 1997) potentially associated with thermal modeling (Gadd and Scrutton, 1997; Vågnes, 1997). These models emphasize that vertical motion of the transform margin relate also strongly to coupling or uncoupling of lithospheric plates across the continent/ocean boundary. Before Leg 159, very little information was available on the amplitude and timing of the vertical motion at the transform margins. As the sedimentation was thought to be almost continuous along the northern slope of the uplifted CIG marginal ridge, Sites 959 and 960 were designed to provide these key data.

According to seismic sections across the transform margin (Figs. 2, 3) and to results of Leg 159 (Mascle, Lohmann, Clift, et al., 1996), the oldest sedimentary unit sampled in the area consists of a deformed siliciclastic sequence, deposited in lacustrine, deltaic to marine environments, dated late Albian-early Cenomanian only at Site 962. The 


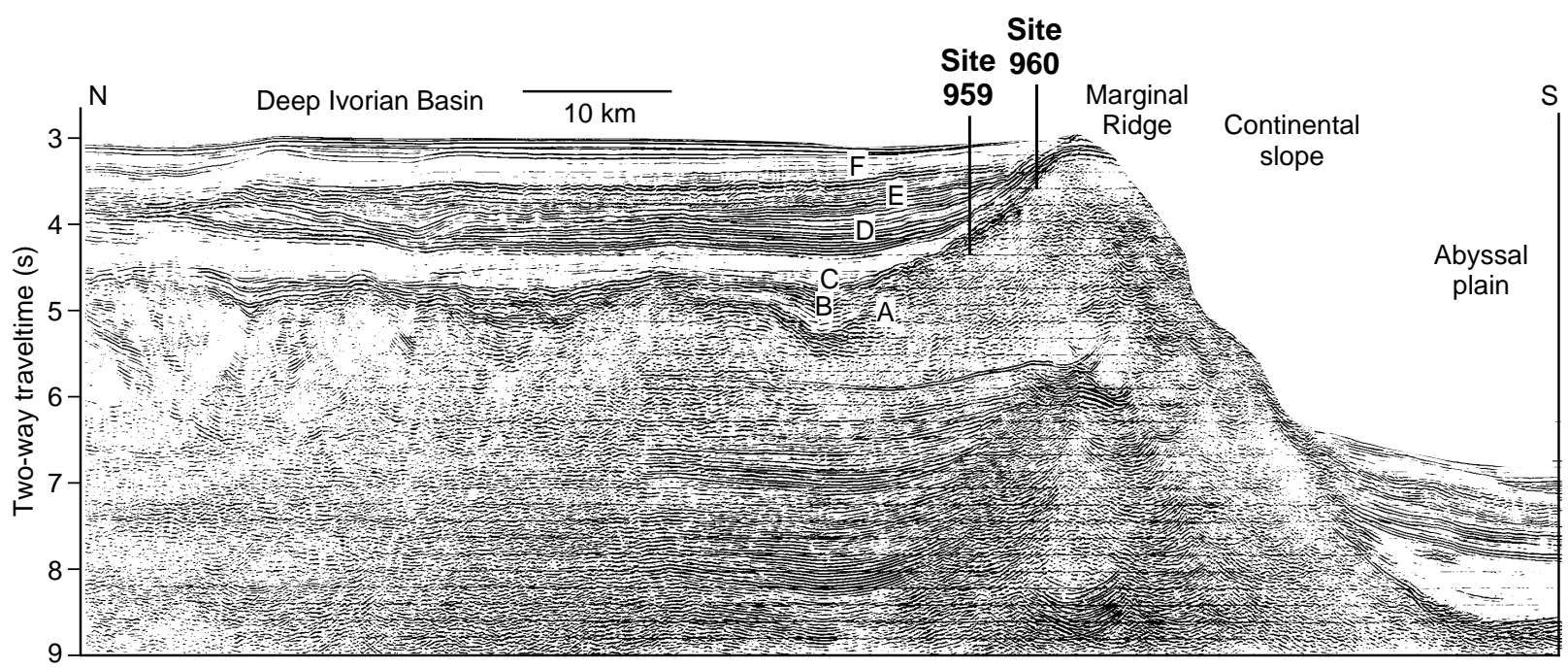

Figure 2. Migrated seismic line MT02 across (from north to south) the deep Côte d'Ivoire-Ghana divergent basin, the marginal ridge, the continental slope, and the Gulf of Guinea abyssal plain. The marginal ridge and the oceanic crust of the Gulf of Guinea are overlain by thick undeformed sedimentary sequences. Main seismic units are shown according to Basile et al. (1996).

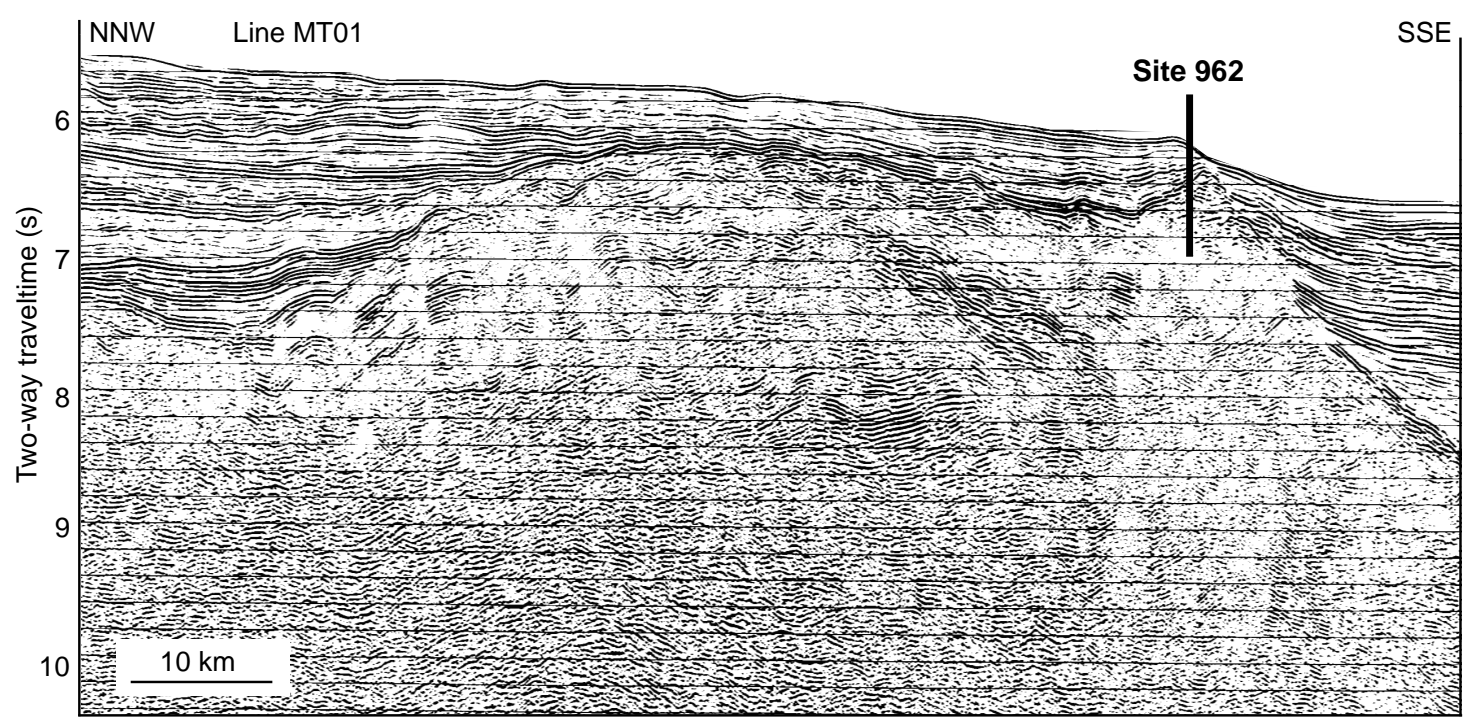

Figure 3. Migrated seismic line MT01 across (from north to south) the deep Ivorian Basin, the buried termination of the Côte d'Ivoire-Ghana marginal ridge, the minor ridge where Site 962 is located, and the oceanic crust of the Gulf of Guinea.

real thickness of this unit is still unknown, but reaches at least several kilometers. Scientific dives along the southern continental slope identify this unit along an almost 3-km-thick section (Mascle et al., 1993), and seismic data show several unconformities at depth within this basal unit (Lamarche et al., 1997). At all Leg 159 sites, this lower unit has been deformed and heated before an erosional phase. Above this major unconformity, the overlying sediments differ from site to site. At Sites 959 and 960, the sediments consist of upper Albian to Turonian-Coniacian periplatform deposits; at Site 961, they are late Paleocene open-marine biogenic siliceous deposits; and at Site 962, the overlying sediments are late Albian to Cenomanian biosiliceous deposits. After Coniacian times, the sedimentation is highly condensed up to the upper Paleocene at Sites 960 to 962, and only from the upper
Coniacian to the upper Santonian at Site 959. In the Upper Cretaceous and Paleocene, sedimentation is known only at Site 959, where a thick sequence of black claystones was deposited. During Cenozoic times, sedimentation covered the whole area. The sediments chiefly consist of biosiliceous deposits during Eocene times, and show occurrences of palygorskite at Sites 960 and 961 (Pletsch, Chap. 15, this volume). The Neogene succession comprises thick sequences of pelagic and hemipelagic oozes and chalks.

In this paper, our aim is to emphasize the new results obtained onshore since the completion of Leg 159 . Sedimentary analysis, including paleoenvironmental studies, are especially useful to estimate the depths and vertical motion recorded by the transform margin, and in turn to estimate the subsidence and uplift evolution, which was one 
of the principal objectives of Leg 159. Deformation analysis has also been developed to determine the tectonic setting, to date it, and to correlate the tectonic and geodynamic evolutions. To evaluate the thermal regime operating on the transform margin was also one of the main objectives of Leg 159 to determine if, how, and when subsidence and uplift were affected by thermal events. This new set of data enables us to propose an updated and more reliable scenario depicting the formation of the CIG Transform Margin, and to briefly consider the consequences for previous transform margin models.

\section{INTRACONTINENTAL TRANSFORM (STAGE 1) Sedimentation}

The deepest sediments recovered at each site of Leg 159 always belong to deformed siliciclastic sequences bounded upward by an erosional or angular unconformity. The sedimentary environments vary from intracontinental lacustrine sediments (Site 960, Subunit VB) to transitional marine (Site 960, Subunit VA; Site 959, Site 961) and open marine basin (Site 962) (Mascle, Lohmann, Clift, et al., 1996).

From the sediment character, the deepest sediments recovered at Site 960 have been interpreted as gravity-driven deposits in deeplacustrine environments (Mascle, Lohmann, Clift, et al., 1996). In the upper part of this sequence, a transition to shallower and brackish-water environments has been determined from the grading into coarser sandstones, the appearance of pyrite (Mascle, Lohmann, Clift, et al., 1996), and the sulfur geochemistry (Hisada et al., Chap. 13, this volume). A comparable transition has been proposed by Strand (Chap. 12 , this volume) within the oldest sediments at Site 959, which grade upward from laminated lacustrine and deltaic deposits to shallowshelf sandstones and claystones that also contain pyrite and a few marine foraminifers (Holbourn and Moullade, Chap. 28, this volume). Moreover, siliciclastic sediments cropping out along the nearby southern continental slope are also considered to have been deposited in a very shallow marine deltaic environment (Guiraud et al., 1997b). In contrast, siliciclastic sediments from Sites 961 and 962 were deposited into an open marine environment, indicated by the abundance of pyrite and the occurrence of nannofossils and/or foraminifers. Sedimentation depths at Site 961 are thought to have been greater than the shoreface, whereas at Site 962 sediments were deposited in a relatively deep, pelagic, sediment-starved basin (Mascle, Lohmann, Clift, et al., 1996). From benthic foraminifer assemblages, Holbourn and Moullade (Chap. 28, this volume) have proposed an outer shelf to upper bathyal sedimentary environment for this Site, with periodical deposition of allochthonous components derived from shallower sources (inner to middle shelf) and eroded older sediments (early Albian to late Albian in age).

On board, this basal siliciclastic sequence was dated late Albianearly Cenomanian only at Site 962 (Mascle, Lohmann, Clift, et al., 1996). This dating has been confirmed by postcruise studies (latest Albian to earliest Cenomanian according to Holbourn and Moullade [Chap. 28, this volume]; late Albian according to Bellier [Chap. 27, this volume], and Oboh-Ikuenobe et al. [Chap. 25, this volume]; early Cenomanian according to Masure et al. [Chap. 24, this volume]). At other sites, the lack of marine fossils reduced the accuracy of dating. From pollen analysis, however, Masure et al. (Chap. 24, this volume) proposed an early Aptian to middle Albian age for this basal section at Sites 959 and 960, and a middle Albian age at Site 961. At Site 959, Holbourn and Moullade (Chap. 28, this volume) also determined from foraminifer assemblages a late Aptian to early Albian age at the top of the siliciclastic unit. Finally, samples recovered by piston coring, dredging, and diving along the southern continental slope tend to indicate a middle to latest Albian age (Klingebiel, 1976; L. Grosdidier, pers. comm., 1989; Mascle et al., in press).
As a consequence, the differences in depositional environments of the siliciclastic unit between each Leg 159 site appear associated with a discrepancy in sedimentation timing. The oldest retrieved sediments are located at Sites 959 and 960, and were deposited in intracontinental basins during an early Aptian to middle Albian period. The sedimentation became shallow marine at both sites during late Aptian to early Albian times, and then lost its continental character in this area. During the middle Albian, sedimentation was marine in a shallow deltaic environment along the future southern continental slope, and slightly deeper at Site 961. Finally, during late Albian, sedimentation took place in an approximately 200 -m-deep open marine environment at Site 962.

\section{Deformation}

Successive deformation stages, from synsedimentary to syndiagenesis and postlithification, can be observed in the siliciclastic sediments.

Synsedimentary to syndiagenesis tectonic structures are mainly related to basin instabilities during deposition of Early Cretaceous sediments. These features include mass sliding (convolute laminations and slumps), water-escape structures, listric normal faults, small-scale horsts and grabens (Benkhelil et al., Chap. 2, 3, this volume), and quartz veins (Guiraud et al., 1997a). All of the early deformational structures precede the tilting of strata, and are though to be related to extension parallel to bedding. Seismic shocks and slope instabilities have been proposed as potential driving mechanisms for this first deformational stage.

Postsedimentary tectonic structures comprise asymmetric microfolds, pop-up structures, and associated reverse and normal faults, later on crosscut by hydrothermal veins (Benkhelil et al., Chap. 2, this volume). Only little direct evidence for strike-slip motion (horizontal slickensides) was observed on samples from Holes 960A and 962D (Mascle, Lohmann, Clift, et al., 1996). However, vertical shear faults with vertical slickensides associated with nascent cleavage and crenulation have been interpreted as indicative of flower positive structures. Associated normal and reverse slips seen in steep fault zones, as well as important and sudden dip variations (from vertical to horizontal dips downhole), have also been tentatively related to positive flower structures, especially at Hole 962D. At Hole 961B, a 20-m-thick highly deformed zone may represent one of the major shear zones cutting across the marginal ridge (Mascle, Lohmann, Clift, et al., 1996). Finally, veining occurs at all sites, and, at least in Hole 962D, seems to postdate folding and faulting, but to predate strata tilting (Mascle, Lohmann, Clift, et al., 1996).

Unfortunately, the true orientations of all those structures remain unknown, because the lack of Formation MicroScanner (FMS) data in the Early Cretaceous formations has precluded any core reorientation. Similarly, because of the magnetic weakness of the sediment, paleomagnetic results also failed to allow reorientation of the cores as expected and did not succeed in demonstrating any rotation about the vertical axis (Allerton, Chap. 20, this volume). It is important to note, however, that, except at Site 959 where it appears less pronounced, tectonic deformation is quite similar in Early Cretaceous sediments recovered all along the marginal ridge.

Dating the deformed sediments provides a lower limit for the age of the deformation. As the deformed sequences are upward bounded by an erosional unconformity at all sites, we cannot determine the thickness of the sedimentary sequence which was eroded after deposition. However, the first sediments above the unconformity provide an upper boundary to date the deformation. These sediments are late Albian in age at Site 959 (Watkins et al., Chap. 26, this volume), upper Turonian at Site 960 (Watkins et al., Chap. 26, this volume), late Paleocene at Site 961 (Shafik et al., Chap. 32, this volume), late Albian in Holes 962C and 962D (Mascle, Lohmann, Clift, et al., 1996), and 
late Albian (Bellier, Chap. 27, this volume) to early Cenomanian (Watkins et al., Chap. 26, this volume) in Hole 962B. Note that Holes $962 \mathrm{~B}$ and $962 \mathrm{C}$ were not deep enough to encounter the unconformity. These results strongly constrain the deformation at Site 962 to be late Albian in age, and suggest no noticeable hiatus associated with the unconformity. At Site 961, deformation took place between the middle Albian and late Paleocene, between the early Aptian to middle Albian and upper Turonian at Site 960, and between the early Aptian to middle Albian and late Albian at Site 959. So, assuming the deformation was contemporaneous at all sites implies a late Albian deformational stage.

\section{Thermal Data}

Ages provided by fission-track analysis can improve the dating of the deformation. This method provides time constraints for apatite cooling between $120^{\circ}$ and $60^{\circ} \mathrm{C}$. According to shipboard analysis, the deformed siliciclastic sedimentary unit is the only one that was subjected to high-temperature diagenetic conditions, which were not encountered above the unconformity (Mascle, Lohmann, Clift, et al., 1996).

Shipboard analysis of thermal maturation of clays is confirmed by shore-based studies (Holmes, Chap. 7, this volume), and is consistent with data on organic material obtained on board (Mascle, Lohmann, Clift, et al., 1996) and later on shore (Oboh-Ikuenobe et al., Chap. 25, this volume; Masure et al., Chap. 24, this volume). Beneath the unconformity, the sediments were heated at all sites, with a probable exception at Site 962, where differences in thermal maturation between organic material (immature according to Masure et al. [Chap. 24, this volume] and Mascle, Lohmann, Clift, et al. [1996]) and clays (more or less heated, Holmes, Chap. 7, this volume) can be explained by resedimentation of eroded thermally mature sediments mixed with immature sediments and organic material in variable amounts (Holmes, Chap. 7, this volume). Nothing has been heated above the unconformity, with the exception of resedimented material (Holmes, Chap. 7, this volume). The temperatures reached below the unconformity were estimated to be between $120^{\circ}$ and $180^{\circ} \mathrm{C}$ according to clay transformations (Holmes, Chap. 7, this volume) and fluid inclusions (Lespinasse et al., Chap. 6, this volume), as well as from the absence of metamorphic minerals, such as chlorite stacks that have been found only in sediments recovered from the southern continental slope (Benkhelil et al., 1996 and 1997). Fluid inclusions also indicate that the hydrothermal fluids were emplaced at low pressure, between 10 and $20 \mathrm{MPa}$ (1000- to 2000-m depth assuming hydrostatic pressure, 500- to 1000-m depth assuming lithostatic pressure).

Apatite fission tracks provided three groups of ages: $110 \mathrm{Ma}$ (early Albian), $90 \mathrm{Ma}$ (Turonian), and 80 to $70 \mathrm{Ma}$ (Campanian to Maastrichtian, only found $50 \mathrm{~km}$ east of the drilled area and not discussed in this paper), which are not located in the same areas (Bouillin et al., 1997; Bouillin et al., Chap. 5, this volume; Clift et al., Chap. 4, this volume). The length of fission tracks indicates that the cooling between $120^{\circ}$ and $60^{\circ} \mathrm{C}$ was fast everywhere.

A cooling event below $60^{\circ} \mathrm{C}$ at $110 \mathrm{Ma}$ has been documented at Sites 959 and 960. Clift et al. (Chap. 4, this volume) interpret this result as reflecting cooling related to erosion of the sediment source, and subsequently no substantial heating above $60^{\circ} \mathrm{C}$ after the sedimentation. In our opinion, this assessment disagrees with the many other data that indicate an in situ heating above $120^{\circ} \mathrm{C}$ (see above). Rather, we agree with the hypothesis proposed by Bouillin et al. (Chap. 5, this volume), who believe that the apatite crystals were heated in situ after their deposition into the siliciclastic sedimentary sequence, and then cooled $\sim 110 \mathrm{Ma}$ as a consequence of a rapid erosional unroofing. This interpretation implies an Aptian age (older than $110 \mathrm{Ma}$ ) for the sedimentary sequence that is not in contradiction with palynologic dating at those sites (early Aptian to middle
Albian age, Masure et al., Chap. 24, this volume). This interpretation also implies that the deformation postdated by the unconformity is also $>110$ Ma. Finally, important diachronisms appear between Sites 959 and 960 on the one hand and Site 962 on the other: sedimentation of the siliciclastic sequence took place from the Aptian at Sites 959 and 960 to late Albian at Site 962; deformation occurred prior to the early Albian at Sites 959 and 960 and during the latest Albian at Site 962; and erosional surfaces were created during the early Aptian at Sites 959 and 960 and during the latest Albian at Site 962.

Two samples providing apatite fission-track ages require special attention. One sample, from below the unconformity at Site 959 (Cores 159-959D-73R and 74R), yields an age of 88 Ma for apatite cooling (Clift et al., Chap. 4, this volume). This age has been obtained with a very high relative error $(20 \%$ instead of $2 \%$ to $4 \%$ for the other samples in the same study), and postdates the unconformity and the end of any evidence of sediment heating by at least 10 m.y. We thus consider that this date should be discarded. The second peculiar sample comes from Turonian limestones in Hole 960A (Cores 159-960A$37 \mathrm{R}$ and $38 \mathrm{R}$ ). In this sample, the apatites are obviously reworked as many other metamorphic and siliciclastic clasts are found in these limestones (Mascle, Lohmann, Clift, et al., 1996).

With the exception of the one sample from Hole 959D (see above), 90-Ma fission-track ages have been obtained on apatites from samples retrieved during dives along the nearby southern continental slope (Bouillin et al., 1997) and from one sample from Site 961 (Bouillin et al., Chap. 5, this volume). Two hypotheses can be proposed for such cooling ages: (1) a second thermal event took place during the late Albian to Cenomanian times (Bouillin et al., Chap. 5, this volume) that did not affect the apatites at Sites 960 and 959, only a few kilometers north of the sampling sites; or (2) apatite grains were heated by the same thermal event in both the southern-slope area and Sites 959 and 960, but were still too deeply covered during the Albian and Cenomanian times to be affected by cooling. However, it is difficult to support this second hypothesis if the assumed middle Albian sedimentation age can be confirmed. In any case, near the Cenomanian/Turonian boundary, these rocks were unroofed by a second erosional event (see below in continent/ocean transform stage).

\section{CONTINENT/OCEAN TRANSFORM (STAGE 2)}

Only two sites have yielded information on the sedimentary environments prevailing in Cenomanian times. At Site 962, the sediment still contained calcareous nannofossils during the early Cenomanian (Watkins et al., Chap. 26, this volume), but then the site passed below the local carbonate compensation depth (CCD) and the sedimentation became dominantly siliceous (chert and porcellanite) up to the Miocene (Mascle, Lohmann, Clift, et al., 1996). Together with this sudden subsidence from outer shelf to deeper depth, the sediment accumulation rates dramatically decreased $(1-2 \mathrm{~m} / \mathrm{m} . \mathrm{y}$.) reflecting starved conditions at this site during the Late Cretaceous (Erbacher, Chap. 29, this volume; Watkins et al., Chap. 26, this volume). By comparison, detrital limestones were deposited at Site 959 in a middle shelf environment (Oboh-Ikuenobe et al., Chap. 25, this volume) during the late Albian to early Cenomanian, while the middle and late Cenomanian are missing. These limestones were redeposited from a shallow reef, bordering a southern standout uplifted area, which provided the quartz sands mixed together with the limestones.

The erosional surface observed on seismic lines all along the northern slope of the marginal ridge cannot be followed within the Ivorian Basin (Fig. 2), where sedimentation is assumed to have been continuous during Late Cretaceous times. This indicates that the northern marginal ridge slope existed since late Albian to early Cenomanian times, when continuous marine sedimentation occurred in the Ivorian Basin, a reef colonized shallow areas south of Site 959, and 
southward areas (probably including Site 960 where no late Albianearly Cenomanian sediments have been documented) were emerged and submitted to erosion. As geodynamic models imply continuous strike-slip motion by that time, and as there is no deformation recorded in the sediments north of the ridge, we suspect that the active transform-fault zone was located south of this emerged ridge. The erosion of this ridge during Turonian-Coniacian times may have resulted in the creation of the southern continental slope, recorded by the cooling of apatite crystals below $60^{\circ} \mathrm{C}$ around $90 \mathrm{Ma}$ (see above).

During Turonian to early Coniacian times, a comparable paleotopography prevailed, but the shallow reef migrated from the northern slope to the present-day crest of the marginal ridge. This migration may be a consequence either of the subsidence of the whole ridge or of sea-level rise. At Site 959, the limited thickness (only $19 \mathrm{~m}$ ) of late Albian limestones is probably related to this change in location of the coastal line. At Site 960, the Turonian-Coniacian limestone sequence reaches approximately $160 \mathrm{~m}$ of coarse limestones mixed with siliciclastic grains derived from the erosion of uplifted older sediments or of metamorphic basement (Mascle, Lohmann, Clift, et al., 1996; Marcano et al., Chap. 8, this volume). The sediments deposited during the same time at Site 959 are only $15 \mathrm{~m}$ thick, and contain significantly thinner clasts and at least two hardgrounds indicating drastic sediment starvation. The main cause of this starvation is probably a relative sea-level highstand, when the carbonate and siliciclastic sedimentation was restricted to the shore zone. However, the occurrence of pelagic and hemipelagic layers in the limestone unit at Site 960 and their absence at Site 959, together with the presence of phosphatic pebbles and reworked nannofossils in the Turonian of Site 959 (Watkins et al., Chap. 26, this volume), suggest that the steepness of the slope can also explain the very low sedimentation rates on the northern slope of the marginal ridge.

Reef-type sedimentation and siliciclastic input suddenly ceased together in early Coniacian times at both Sites 959 and 960 . There is no evidence for uplift or aerial exposure of the limestones at that time; this change in sedimentation was likely caused by a sudden and fast deepening of the marginal ridge (Oboh-Ikuenobe et al., Chap. 25, this volume). The end of reef sedimentation is dated middle Coniacian (Watkins et al., Chap. 26, this volume) or Coniacian-Santonian (Bellier, Chap. 27, this volume) in Hole 960C, between Maastrichtian and Santonian in Hole 960A (Oboh-Ikuenobe et al., Chap. 25, this volume), and very precisely early Coniacian (Watkins et al., Chap. 26, this volume) in the continuous section of Hole 959D. It is worthy to note that this sudden subsidence occurred almost 10 m.y. after a similar sudden early Cenomanian deepening documented at Site 962, some $50 \mathrm{~km}$ to the west-southwest of Sites 959 and 960.

During Coniacian and Santonian times, the marginal ridge crest (Site 960) and its upper northern slope (Site 959) were sediment starved in a high-productivity environment. At both sites, similar phosphatic hardgrounds, fish debris, and glauconitic grains are interbedded in nannofossil claystones draping the ridge slope and crest (Mascle, Lohmann, Clift, et al., 1996). Those sediments result in very high peaks of natural gamma ray recorded by logging. As for the Turonian-early Coniacian interval, the northern slope steepness and instability are documented by hardground reworking.

\section{PASSIVE MARGIN EVOLUTION (STAGE 3)}

From the Campanian to present times, the CIG continental margin experienced a more or less continuous subsidence. The transition from the previous stage is not recorded by a change in sedimentation, which is still dominantly clayey in character, but is well marked by a change in sediment distribution. At Site 960, the almost complete lack of sedimentary record from the Santonian to the Maastrichtian may be due to the action of bottom currents. At Site 959, a thick sequence of organic-rich black claystones (transparent seismic unit $\mathrm{C}$ in Fig. 2) onlaps the northern slope of the marginal ridge. The age of this sequence varies slightly from one study to another (see Moullade et al., Chap. 35, this volume) but ranges without an observed hiatus from early Campanian to the Paleocene/Eocene boundary. The dips of the bedding surfaces measured on cores (Mascle, Lohmann, Clift, et al., 1996) or on the borehole using FMS images (Basile et al., Chap. 9, this volume) reach a maximum at the bottom of the claystone unit (estimated to be $40^{\circ}-45^{\circ}$ from core measurements corrected for the hole deviation) and then decrease to $15^{\circ}$ at the top of unit. This clearly indicates a progressive northwestward tilting coeval with the sedimentation of the claystone unit.

The deepening is also recorded by foraminifer assemblages. At Site 959, the paleobathymetry changed from an upper bathyal depth (Holbourn and Kuhnt, Chap. 30, this volume) to a depth below the CCD in the earliest Campanian, and an increase to abyssal depths (2500-3000 m, which is the present depth of the sediments) in the late Maastrichtian, according to Kuhnt et al. (Chap. 31, this volume). A comparable record of deep environment is reported by Bignot (Chap. 33, this volume) for Site 960 in the late Eocene, where the depth is estimated to be $2 \pm 1 \mathrm{~km}$ (similar to the present depth of the sediment: $2170 \mathrm{~m}$ ). The subsidence of the marginal ridge is then thought to have been almost complete by the beginning of the Cenozoic.

Above the claystone unit, the overlying sequences are made of pelagic sediments, predominantly siliceous at all sites during Eocene times, then more calcareous. Changes in sediment character are then mainly driven by changes in productivity in sea-surface waters and by slope instability. During the Eocene, high-productivity surface waters allowed the sedimentation of a thick porcellanite unit at Site 959. As currents had by that time swept sediments off of the crest of the marginal ridge, this unit appears drastically thinner at Sites 960, 961, and 962. Authigenic palygorskite developed during the early Eocene at Sites 960 and 961, and possibly at Site 962, indicating warm and saline deep waters (Pletsch, Chap. 15, this volume).

During the early Eocene, slope instability is attested by reworking of palygorskite clays at Site 959, but is well evidenced chiefly in middle Eocene times by the simultaneous occurrence at both Sites 959 and 960 of slumping and normal faulting (Mascle, Lohmann, Clift, et al., 1996; Pickett, Chap. 1, this volume), as well as by hiatuses and nannofossil reworking at Site 959 (Shafik et al., Chap. 32, this volume). This event is localized at $750 \mathrm{~m}$ below seafloor (mbsf) in Hole 959D, and has been recorded by drastic changes in all physical properties measured on board or downhole: a decrease in porosity and an increase in resistivity, density, and velocity downhole (Mascle, Lohmann, Clift and al., 1996; Janik et al., Chap. 23, this volume; Edwards, Chap. 22, this volume). Structural measurements also display an important change between the upper part of the hole, where bedding dips slowly increase from a few degrees at the top to $10^{\circ}$ at $750 \mathrm{mbsf}$, and the interval between 750 and $800 \mathrm{mbsf}$, where dips increase rapidly from $10^{\circ}$ to $30^{\circ}$ (Mascle, Lohmann, Clift, et al., 1996; Basile et al, Chap. 9, this volume). In the same 750-800-mbsf interval, brittle deformation also increases and is recorded by numerous normal faults and calcite and quartz veins (Pickett, Chap. 1, this volume). Moreover, hydrothermal calcite is restricted to early Eocene and older sediments. $\delta^{18} \mathrm{O}$ analysis performed on these calcite veins provided a range of temperature from $30^{\circ}$ to $85^{\circ} \mathrm{C}$, but did not indicate the depth those fluids came from (Marcano et al., Chap. 8, this volume).

On seismic records these sediments mark the bottom of seismic unit D (Fig. 2), which is overlain by onlaps. Even if it can be followed regionally on seismic lines, this level does not seem to mark a major tectonic event. The significance of this event is thus not obvious, but the rapid change of bedding dip indicates that a rotation occurred about a horizontal axis, probably induced by sliding of lithified sediments on the slope. This event can then be interpreted either as a new tilting of the northern slope or as sliding on a previous slope in re- 
sponse to a change in sediment composition (an increase in $\mathrm{CaCO}_{3}$ content within the 750-800 mbsf interval). Shafik et al. (Chap. 32, this volume) also noticed that this layer can be time correlated with a sea-level fall.

Finally, after the middle Eocene, the dip of sedimentary beds remains less than $10^{\circ}$, and can probably be explained by differential compaction between the Ivorian Basin and the marginal ridge.

\section{DISCUSSION}

The brief synthesis proposed above allows us to discuss and emphasize several characteristics of the CIG Transform Margin that we consider relevant to the understanding of translational margin evolution.

\section{Vertical Motion of the CIG Transform Margin}

One of the important objectives for drilling a transform margin, such as the CIG margin, was to establish the variations of subsidence and uplift through time and space, and hence to provide more reliable qualitative and quantitative constraints for comparison with thermal or thermomechanical models of transform continent/ocean boundaries. In this section, we summarize the vertical motion recorded by the sediments on the CIG Transform Margin (Fig. 4), as dated and discussed above, then discuss the possible mechanisms that can explain the observed evolution. We should keep in mind, however, that the subsidence history is discussed with respect to sea level, which is also subject to rapid fluctuations.

The first record of subsidence in the CIG area is shown by the Aptian continental to brackish siliciclastic sequence drilled at the bottom of Sites 959 and 960 . Since the beginning of the Albian, those basins were uplifted and submitted to aerial erosion. Site 961 , as well as the area where the southern continental slope will appear later, was probably located inside the subsiding transform zone since the beginning of the Albian. However, the sedimentary record is only known from the middle Albian, again in a deltaic to brackish environment.

Evidence of the first northward tilting of the marginal ridge is seen in late Albian times. Since sedimentation seems to persist throughout Aptian-Albian times within the Ivorian Basin, we believe that this tilting occurred prior to late Albian, and may have possibly occurred contemporaneously with the previous early Albian uplift. We cannot reject that the whole area was already subsiding at that time, but since Site 960 and the southern slope area were still emerged, the subsidence can only be seen in the return of the sea at Site 959, which was at a middle-shelf depth $(\approx 100 \mathrm{~m})$. By comparison, at the same time, Site 962 was at an outer-shelf depth $(\approx 200 \mathrm{~m})$.

During the middle Cenomanian, subsidence increased rapidly at Site 962, which passed below the local CCD. At other sites, the subsidence is thought to persist during the Cenomanian. In Turonian times, the marginal ridge is still subsiding. Site 960 is then below sea level (depth $\approx 100 \mathrm{~m}$ ), but a still-emerged ridge lies south of this site. Moreover, the northern slope instability implies that Site 959 is still deepening, probably faster than Site 960, resulting in continuous northern slope tilting. During the early Coniacian, the subsidence suddenly increased, and the whole margin passed below sea level.

Fast subsidence may have persisted from the early Coniacian to the Santonian, since Site 959 reached the local CCD depth in Campanian times. The deepening of the marginal ridge then slowed down, to stop in Maastrichtian times, when Site 959 approximately reached its present depth. However, the differential subsidence between the ridge top (slow subsidence) and the Ivorian Basin (faster subsidence) resulted in a northwestward tilting of the northern slope of the marginal ridge. The tilting velocity seems to have reached a maximum at the beginning of the Campanian, then progressively decreased up to the Paleocene.

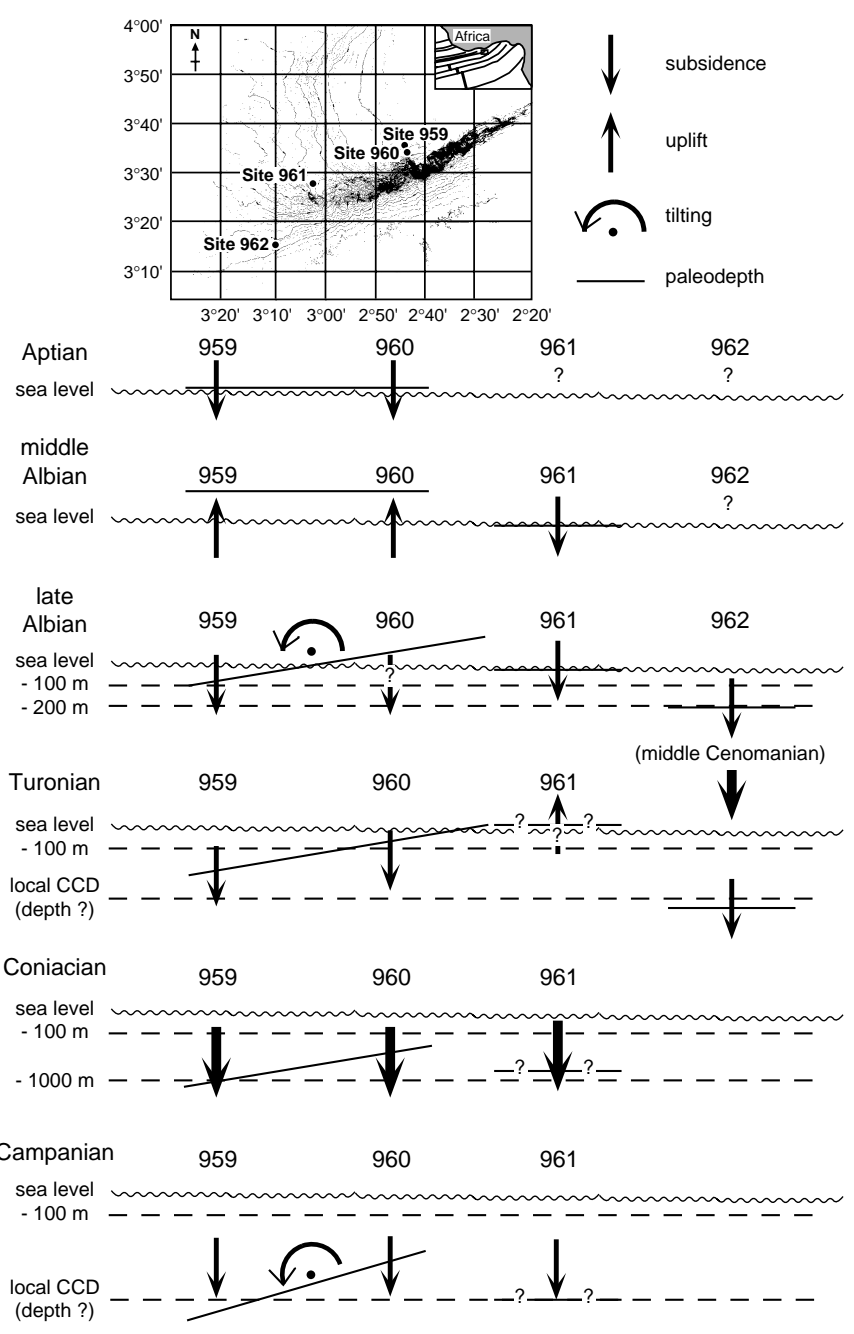

Figure 4. Sketch depicting the vertical motion encompassed by the four Leg 159 sites drilled on the Côte d'Ivoire-Ghana Transform Margin (no scale). Insert shows a bathymetric map and the location of the four sites. The thickness of the subsidence arrow increases with the subsidence rate. During Turonian times, erosion is seen at Site 961, but both uplift above sea level and submarine erosion can be considered.

A paradoxical result from Leg 159 is that time constraints on vertical displacements are now much more precisely defined, especially in the marginal ridge area, than on the global geodynamic evolution, which is still poorly defined between the Aptian and Santonian. As a consequence, vertical motion can only tentatively be linked to the successive stages of transform margin formation. We should also take into account that the studied area is located along the edge of a divergent continental margin, subject to its own thermal subsidence. The subsidence (or uplift) as recorded on the transform margin then results from both vertical motion at the transform and divergent margins, as proposed by Basile et al. (Chap. 9, this volume) from interpretation of FMS data in the postrift sediments at Site 959. With those limitations, we restrict in this section the discussion to the relationships between tectonic events and vertical motion; the effects of thermal events are discussed in the next section.

During the synrift stage (Aptian), the subsidence can be related to the opening of the divergent Ivorian Basin, but is more likely related to strike-slip tectonism, as substantiated by the observed deformation and the geodynamic framework. Because of the strike-slip tectonic 
context, a pull-apart basin can be supposed, but not directly demonstrated. The first uplift and aerial erosion (early Albian) fit with the end of the tectonic activity at Sites 959 and 960, and probably in the whole Ivorian Basin. We believe that this uplift can be contemporaneous to the end of rifting in the Ivorian Basin. Although tectonic activity ceased north of Sites 959 and 960, transform faulting may have continued; the transform zone is thought to have migrated southward, to the present-day southern continental slope. Later, but still during the intracontinental transform stage, the mechanism that produced the Albian tilting of the marginal ridge is not known. Important transpressional deformation of the whole ridge cannot be easily considered, as the earlier Albian unconformity does not seem to be deformed. Tilting can be hypothetically related to the southward transform tectonic activity, or to differences in thermal subsidence between the thinned crust in the nearby Ivorian Basin and its borders. It is also noticeable that the tilting phase slightly precedes the continent/ocean contact, and is correlated to the active transform contact with the thinned crust of the Brazilian rifted margin.

The most striking difference between intracontinental and continent/ocean transform faulting stages concerns the drastic change in crustal thickness across the transform fault. During the intracontinental stage, the crustal thickness of the two domains separated by the transform fault is thought to be more or less similar, except along the border of the southern domain of the Ivorian Basin, which had previously experienced divergent rifting. This sharp contrast in thickness is believed to localize the transform zone on the border of the thinner and weaker crust (Basile et al., 1992, 1993). During the transition from the intracontinental stage to the continent/ocean stage, the Ivorian Basin should have been in tectonic contact with the thinner crust of the Brazilian continental rifted margin, and then with the newly created oceanic crust of the Gulf of Guinea. According to available plate reconstructions, this event is supposed to have occurred around Turonian times, and hence to have been initiated during Cenomanian times. Since Leg 159 holes have not documented deformed CenomanianTuronian sediments while the transform fault was still active, we suspect that the main active transform domain had, by that time, already migrated along the edge of the thinner crust. This transition from intracontinental to continent/ocean stage then may be responsible for a second shift of the transform zone from the area of the present-day southern continental slope and Sites 961 and 962 in Albian times to the edge of the thinned Brazilian crust, and later, to the edge of the oceanic crust, during Late Cretaceous time. The late Albian-early Cenomanian unconformity, seen at Site 962, may correlate with this second southward shift, and in this case would mark the end of the intracontinental phase.

Finally, two episodes of rapid deepening are recorded within the CIG margin's sedimentary cover. The first one is recorded at Site 962 and is post-early Cenomanian in age. Its significance is not well understood, mainly due to a Cenomanian hiatus. The second one, recorded on the marginal ridge at Sites 959 and 960, is early Coniacian in age, and may be correlated with the initiation of the continent/ ocean transform boundary and the subsequent erosion of the southern continental slope.

\section{Thermal Events at the CIG Transform Margin}

In the area investigated by Leg 159 , two thermal events have been recorded by apatite fission track analysis. The origin of those events are not clear, but both Aptian and pre-90-Ma thermal events cannot be correlated to heating by an adjacent oceanic lithosphere, which is quite unlikely at these times when one takes into account the reconstruction of the opening of the south and equatorial Atlantic oceanic areas (e.g., Scotese et al., 1988). Since these thermal events are restricted to deformed sediments, they are thought to be linked to tectonism, either in a fault zone (heating by friction and/or hydrothermalism) or a rapidly subsiding basin where crustal thinning increased the thermal gradients. Because of the southward shift of the active and subsiding tectonic zone between Aptian and Late Cretaceous times, the second thermal event (before $90 \mathrm{Ma}$ ), probably again tectonically induced, can be distinguished from the first one in the southern area.

It does not seem possible to clearly establish the mechanism that allowed unroofing during earlier Albian times. Change from transtension to transpression in a strike-slip regime has been proposed, as well as a postrift unconformity on the border of the Ivorian Basin. However, the second explanation seems to be more accurate because the sedimentation and deformation never stopped during the Albian, but just shifted southward from the rifted area to the transform domain. Whatever the mechanism was, it resulted in a structural inversion in the transform domain. The mechanism for unroofing at $90 \mathrm{Ma}$ is more obvious, as at that time the difference in depth between the edge of the continental margin and the southward oceanic crust induced slope instabilities and important erosion along the southern border of the continental plate.

One of the most significant results from Leg 159 is that there is no absolute (relative to sea level) uplift associated with the contact between the continental crust and a passing hot oceanic accretion center, as previously inferred (Mascle and Blarez, 1987). The only noticeable consequence of this continent-accretion axis contact consists in an increasing tilting of the marginal ridge, which results in an apparent uplift with respect to the more quickly subsiding Ivorian Ba$\sin$. Moreover, there is no record of significant heating of the sedimentary sequence at that time, even in the deeper sediments of the southern continental slope (Bouillin et al., 1997).

Several explanations can tentatively be proposed to explain the absence of any significant thermal uplift related to an adjacent oceanic accretion. First, it should be noted that thermal uplift should have prevailed over thermal subsidence of the adjacent Ivorian Basin, in order to be recorded by changes in sedimentation. Moreover, thermal uplift, if any, may have been substantially reduced by the coupling of continental and oceanic lithospheres (Gadd and Scrutton, 1997). A second possible explanation relates to the absence of significant thermal conduction between the two lithospheres. This can be a consequence of the specific nature of the adjacent oceanic lithosphere, which is supposed to be relatively cold (with very low accretion rates) in fracture zones (Sage et al., 1997a; White et al., 1984). Moreover, the ocean-continent transition is thought to be a highly fractured zone, where efficient vertical circulation of hydrothermal fluids may have strongly restricted horizontal conduction.

Alternative mechanisms to thermally induced uplift are required to better explain the tilting of the marginal ridge since late Albian times, and probably to explain similar tilting of transverse ridges at oceanic transform-fault zones. Because such mechanisms are clearly operating during transform fault tectonic activity, either in an intracontinental, continent-ocean, or intra-oceanic setting, we believe that they may be linked to the transform zone's functioning.

\section{SUMMARY OF THE CIG TRANSFORM MARGIN EVOLUTION}

Within the Côte d'Ivoire-Ghana transform domain, siliciclastic sedimentation began during Aptian times in an intracontinental setting (Fig. 5). Synsedimentary and syndiagenetic, strike-slip-related deformations, as well as a relatively high geothermal gradient, indicate a pull-apart basin located along the southern edge of the rifted Ivorian Basin. Within this domain, the first evidence of a marine environment is late Aptian to early Albian in age. This basin was uplifted and eroded in early Albian times, probably as consequences of the breakup that occurred in the divergent Ivorian Basin and of the subsequent southward shift of the active transform zone. In the new transform domain, a second subsiding area developed, where deltaic 

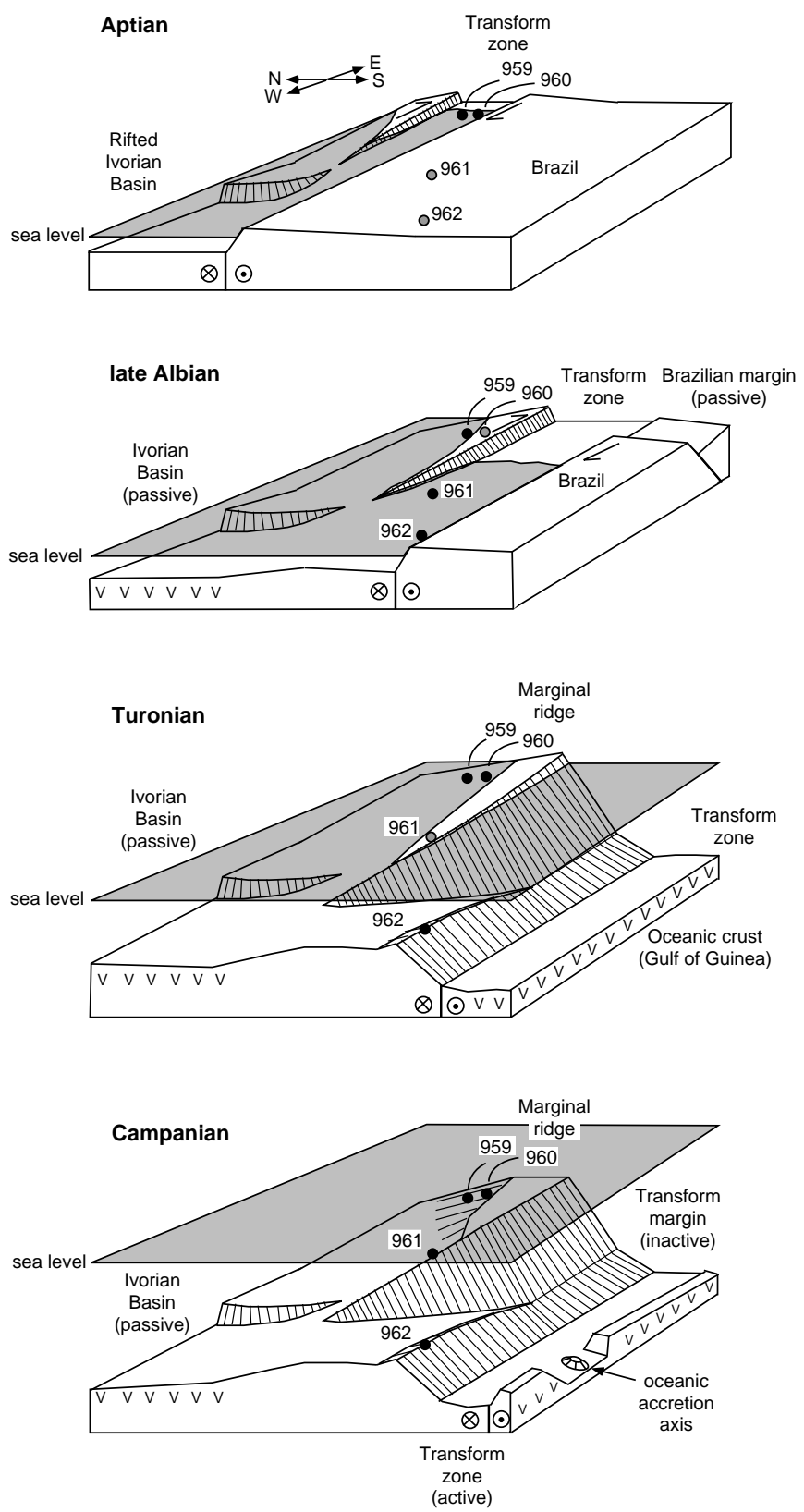

Figure 5. Paleogeographic and tectonic reconstruction of the Côte d'IvoireGhana Transform Margin (see text for comments).

and brackish siliciclastic sediments were deposited from middle to late Albian times in a similar (wrench-related) tectonic and geothermal setting. The final parting between the African and Brazilian continents may be late Albian in age, and may have been recorded by the initiation of northward tilting of the marginal ridge, the cessation of deformation within the continental margin, and a new southward shift of the active transform zone. A reef started then to growth along the northern shoulder of the marginal ridge, while its crest encompassed erosion. During the Late Cretaceous, the transform margin subsided, leading to progressive migration of the reef toward the ridge crest. The subsidence suddenly increased, during the early Cenomanian in the western and deeper domains of the margin, and during early Coniacian along the marginal ridge. It was also during Turonian-Coniacian times that the marginal ridge's southern slope was likely progressively created as a consequence of newly created strong differences in depth between the continental margin and the oceanic crust. From the Coniacian to Santonian, no specific uplift or thermal event can be directly related to the sharp contact between continental and oceanic lithospheres across the active transform fault. An increasing tilt of the marginal ridge, however, occurred after the oceanic accretion axis passed south of the transform margin in Campanian times. After Late Cretaceous times, the Côte d'Ivoire-Ghana Transform Margin experienced a progressive cooling subsidence and has only been submitted to sedimentary changes mainly linked to global oceanographic events since then, with the possible exception of an early Eocene small-amplitude tectonic event.

\section{ACKNOWLEDGMENTS}

J. Lorenzo and J.S. Watkins are acknowledged for detailed reviews of this paper. We are indebted to the entire Leg 159 party (technicians, engineers, and scientists) as well as to the numerous onshore scientists who greatly increased the value of Leg 159 data sets.

INSU-CNRS (Geosciences Marines) has partly supported this study. Publication number 155 from UMR 6526 Geosciences Azur.

\section{REFERENCES}

Basile, C., Brun, J.P., and Mascle, J., 1992. Structure et formation de la marge transformante de Côte d'Ivoire-Ghana: apports de la sismique réflexion et de la modélisation analogique. Bull. Soc. Geol. Fr., 163:207216.

Basile, C., Mascle, J., Popoff, M., Bouillin, J.P., and Mascle, G., 1993. The Côte d'Ivoire-Ghana transform margin: a marginal ridge structure deduced from seismic data. Tectonophysics, 222:1-19.

Basile, C., Mascle, J., Sage, F., Lamarche, G., and Pontoise, B., 1996. Precruise and site surveys: a synthesis of marine geological and geophysical data on the Côte d'Ivoire-Ghana Transform Margin. In Mascle, J., Lohmann, G.P., Clift, P.D., et al., Proc. ODP, Init. Repts., 159: College Station, TX (Ocean Drilling Program), 47-60.

Benkhelil, J., Guiraud, M., Mascle, J., Basile, C., Bouillin, J.-P., Mascle, G., and Cousin, M., 1996. Enregistrement structural du coulissage Afrique/ Brésil au sein des sédiments crétacés de la marge transformante de Côte d'Ivoire-Ghana. C. R. Acad. Sci. Ser. 2, 323:73-80.

Benkhelil, J., Mascle, J., Guiraud, M., Basile, C., and the Equanaute Scientific Team, 1997. Submersible observations of Cretaceous deformations along the Côte d'Ivoire-Ghana transform margin. Geo-Mar. Lett., 17:4954.

Blarez, E., and Mascle, J., 1988. Shallow structure and evolution of the Ivory Coast and Ghana transform margin. Mar. Pet. Geol., 5:54-64.

Bouillin, J.P., Poupeau, G., Labrin, E., Basile, C., Sabil, N., Mascle, J., Mascle, G., Guillot, F., and Riou, L., 1997. Fission track study: heating and denudation of marginal ridge of the Ivory Coast-Ghana transform margin. Geo-Mar. Lett., 17:55-61.

Cande, S.C., LaBrecque, J.L., and Haxby, W.F., 1988. Plate kinematics of the South Atlantic: Chron C34 to present. J. Geophys. Res., 93:1347913492.

Coulon, C., Vidal, P., Dupuy, C., Baudin, P., Popoff, M., Maluski, H., and Hermitte, D., 1996. The Mesozoic to early Cenozoic magmatism of the Benue trough (Nigeria); geochemical evidence for the involvement of the St Helena plume. J. Petrol., 37:1341-1358.

Edwards, R.A., Whitmarsh, R.B., and Scrutton, R.A., 1997. The crustal structure across the transform continental margin off Ghana, eastern Equatorial Atlantic. J. Geophys. Res., 102:747.

Gadd, S.A., and Scrutton, R.A., 1997. An integrated thermomechanical model for transform continental margin evolution. Geo-Mar. Lett., 17:21-30.

Guiraud, M., Benkhelil, J., Mascle, J., Basile, C., Mascle, G., and the Equanaute Team, 1997a. Syn-rift to syn-transform deformation along the Côte d'Ivoire-Ghana transform margin: evidence from deep-sea dives. GeoMar. Lett., 17:70-78.

Guiraud, M., Mascle, J., Benkhelil, J., Basile, C., Mascle, G., and Durand, M., 1997b. Early Cretaceous deltaic sedimentary environment of the 
Ivory Coast-Ghana transform margin as deduced from deep dives data. Geo-Mar. Lett., 17:79-86.

Janssen, M.E., Stephenson, R.A., and Cloetingh, S., 1995. Temporal and spatial correlations between changes in plate motion and the evolution of rifted basins in Africa. Geol. Soc. Am. Bull., 107:1317-1332.

Klingebiel, A., 1976. Sédiments et milieux sédimentaires dans le golfe de Bénin. Bull. Cent. Rech. Explor-Prod. Elf-Aquitaine, 1:129-148.

Lamarche, G., Basile, C., Mascle, J., and Sage, F., 1997. The Côte d'IvoireGhana transform margin: sedimentary and tectonic structure from multichannel seismic data. Geo-Mar. Lett., 17:62-69.

Lorenzo, J.M., and Vera, E.E., 1992. Thermal uplift and erosion across the continent - ocean transform boundary of the southern Exmouth Plateau. Earth Planet. Sci. Lett., 108:79-92.

Lorenzo, J.M., and Wessel, P., 1997. Flexure across a continent-ocean fracture zone: the northern Falkland/Malvinas Plateau, South Atlantic. GeoMar. Lett., 17:110-118.

Mascle, J., and Blarez, E., 1987. Evidence for transform margin evolution from the Côte d'Ivoire-Ghana continental margin. Nature, 326:378-381.

Mascle, J., Blarez, E., and Marinho, M., 1988. The shallow structures of the Guinea and Ivory Coast-Ghana transform margins: their bearing on the Equatorial Atlantic Mesozoic evolution. Tectonophysics, 188:193-209.

Mascle, J., Guiraud, M., Basile, C., Benkhelil, J., Bouillin, J.P., Cousin, M., and Mascle, G., 1993. La marge transformante de Côte d'Ivoire-Ghana: premiers résultats de la campagne Equanaute (Juin 1992) [The Côte d'Ivoire-Ghana transform margin: preliminary results from the Equanaute cruise (June 1992)]. C. R. Acad. Sci. Ser. 2, 316:1255-1261.

Mascle, J., Guiraud, M., Benkhelil, J., Basile, C., Bouillin, J.P., Mascle, G., Cousin, M., Durand, M., Dejax, J., and Moullade, M., in press. A geological field trip to the Côte d'Ivoire-Ghana transform margin. Oceanol. Acta.

Mascle, J., Lohmann, G.P., Clift, P.D., et al., 1996. Proc. ODP, Init. Repts., 159: College Station, TX (Ocean Drilling Program).
Sage, F., Pontoise, B., Mascle, J., and Basile, C., 1997a. Structure of oceanic crust adjacent to a transform margin segment: the Côte d'Ivoire-Ghana transform margin. Geo-Mar. Lett., 17:31-39.

Sage, F., Pontoise, B., Mascle, J., Basile, C., and Arnould, L., 1997b. Crustal structure and ocean-continent transition at marginal ridge: the Côte d'Ivoire-Ghana marginal ridge. Geo-Mar. Lett., 17:40-48.

Scotese, C.R., Gahagan, L.M., and Larson, R.L., 1988. Plate tectonic reconstructions of the Cretaceous and Cenozoic ocean basins. Tectonophysics, $155: 27-48$.

Sibuet, J.-C., and Mascle, J., 1978. Plate kinematic implications of Equatorial Fracture Zone trends. J. Geophys. Res., 83:3401-3421.

Todd, B.J., and Keen, C.E., 1989. Temperature effects and their geological consequences at transform margins. Can. J. Earth Sci., 26:2591-2603.

Vågnes, E., 1997. Uplift at thermo-mechanically coupled ocean-continent transforms: modeled at the Senja Fracture Zone, southwestern Barents Sea. Geo-Mar. Lett., 17:100-109.

White, R.S., Detrick, R.S., Sinha, M.C., and Cormier, M.H., 1984. Anomalous seismic crustal structure of oceanic fracture zones. Geophys. J. R. Astron. Soc., 79:779-798.

Wilson, M., 1992. Magmatism and continental rifting during the opening of the South Atlantic Ocean: a consequence of Lower Cretaceous superplume activity? In Storey, B.C., Alabaster, T., and Pankhurst, R.J. (Eds.), Magmatism and the Causes of Continental breakup. Geol. Soc. Spec. Publ. London, 68:241-255.

Date of initial receipt: 20 May 1997

Date of acceptance: 13 August 1997

Ms 159SR-048 